\title{
Assessment of environmental indicators on the topolithosequence with a particular reference to soil development in south Sulawesi, Indonesia
}

\author{
Zulkarnain Chairuddin ${ }^{1}$, Sumbangan Baja ${ }^{1,}$, Kaimuddin $^{2}$, Rahim Darma ${ }^{3}$ \\ ${ }^{1}$ Dept of soil science, Faculty of agriculture, Hasanuddin university, *Center for Regional Development and Spatial Information \\ (WITARIS), Makassar, South Sulawesi 90245 Indonesia \\ ${ }^{2}$ Dept of agronomy, Faculty of agriculture, Hasanuddin university, Makassar, South Sulawesi 90245 Indonesia \\ ${ }^{3}$ Dept of agriculture socio-economic, Faculty of agriculture, Hasanuddin university, Makassar, South Sulawesi 90245 Indonesia
}

\section{Email address:}

mz_vip01@yahoo.co.id(Z.Chairuddin),sbja02@yahoo.com.au(S. Baja), kaimuddin@yahoo.com(Kaimuddin), rdarma@unhas.ac.id(R. Darma)

\section{To cite this article:}

Zulkarnain Chairuddin, Sumbangan Baja, Kaimuddin, Rahim Darma. Assessment of Environmental Indicators on the Topolithosequence with a Particular Reference to Soil Developmemt in South Sulawesi, Indonesia. International Journal of Environmental Monitoring and Analysis, Vol. 1, No. 3, 2013, pp. 105-110. doi: 10.11648/j.ijema.20130103.16

\begin{abstract}
A study was carried out to assess environmental indicators and to investigate the role of soil mineralogy on the topolithosequence with a particular reference to soil development in South Sulawesi, Indonesia. Soil profiles were selected based on the differences in altitude, slope gradient, and rock unit. The soil profiles can be respectively described as follows: P1 (140 meters above sea level, 20\%, breksi and lava); P2 (60 meters above sea level, 15\%, sedimentary rock); P3 (20 meters above sea level, 3\%, alluvium sediment), and P4 (5 meters above sea level, $0 \%$, alluvium sediment). In the identification of sand fraction mineral for each profile, minerals such as Garnet, Apatite, Olivine, Hornblende, Biotite, Feldspar, Muscovite, Quartz, Hematite, and Pyrite were found. The quartz mineral can be used as a topolithosequence indicators regarding soil development and its vulnerability against pedo-transfer functions. According to soil development, the profiles can be arranged as follow: $\mathrm{P} 4>\mathrm{P} 3>\mathrm{P} 2>\mathrm{P} 1$. The X-ray diffractogram analysis of soil profiles indicates that the diffractogram peaks are $3.2 ; 3.4 ; 3.56 ; 9.9 ; 12.4 ; 14.5 ; 15.4 ; 16.8$; and $17.7 \mathrm{~A}^{\circ}$ which are identified as montmorillonite clay mineral, and the diffractogram peaks 7.2 and $10.1 \mathrm{~A}^{\circ}$ are halloysite. Meanwhile, the diffractogram peaks $3.58,3.59$, and 7.15 $\mathrm{A}^{\circ}$ are identified as kaolinite. Each soil profile with its diffractogram peak signifies that all profiles have clay mineral montmorillonite, halloysite, and kaolinite, except for soil profile P1 only which has montmorillonite, and halloysite. Therefore, it could be concluded that P1 has experienced longer weathering than P2, P3, and P4, although it never leads to a soil development. The overall results of both sand fraction minerals and clay minerals signify that the soil development rate of each profile corresponds to altitude and slope. This eventually indicates that the weathering is transported in its lateral translocation nature, and reveals different types and levels of environmental indicators related to soil development.
\end{abstract}

Keywords: Environmental Indicators, Pedo-Transfer, Soil Development, Topolithosequence, Weathering

\section{Introduction}

Assessment of environmental indicators within the context of soil development is considered as one of the crucial stages in a long term environmental monitoring, because it relates to soil formation and pedo-transfer functions. Soil formation is the result of reciprocal treatment between various geomorphic and pedogenic processes related to soil organic structure, and it gives rise to a dynamic zone. Within a topolithosequence, soil characteristics may appear as a result of a function of topography and rocks as influenced by weather and organism at a certain period of time [1].

The interaction between soil and topography constitutes the basis of soil catena. That topographical factor can obviously influence other factors in the process of soil formation. In a broader scope, the meaning of soil catena can be related to weather, and in a even much broader sense can be related to the essence of soil materials. Eventually, catena concept has a role in the observation of observable primary process that causes various soil characteristics. In 
this context, environmental indicators derived from soil factors can be estimated from textural classes using qualitative pedo-transfer functions [2].

The relationship between catena (in this paper: topolithosequence) and soil characteristics in a geographical perspective depends on the function intensity of each soil forming factor. In the region with a certain slope, it will be found a close relationship between the position and the soil characteristics such as topsoil depth, organic material content at the surface layer, texture, relative humidity of profile, dissolved salt content, soil colour, degree of soil horizon differentiation, type and rate of rock development, the characteristic of the main material, and so forth [3].

On the other hand, as the pedogenesis concept starting from the formation and development of soils to a mixture of various materials, the erosion and sedimentation processes occurring in a certain site always have a close relationship with formation of certain type of soil in that site. The characteristics of the soils formed as a mixture of different types of materials highly depend on its forming components. The most significant soil forming component is soil mineralogy, which is considered as a static environmental indicator.

Within the context of environmental monitoring, it is therefore important to conduct a study on the role of soil physics and mineralogy and its resulting characteristics in various soil development stages in different topolithosequence. The primary aim of this study is to assess basic environmental indicators in soil characteristics on the topolithosequence. This study will give a picture of soil development rate on the topolithosequence due to differences in altitude, topography and geology, and pedo-transfer process that occurs in each site. This study also will provide a reference to many different steps of environmental monitoring in different altitude, topography and geology, and pedo-transfer processes.

\section{Materials and Method}

\subsection{Location and Description of Study Area}

This study was carried out in Soppeng Regency, South Sulawesi, Indonesia, starting from the depression area of Tempe Lake moving westward along Batu-Batu River. Selection of locations of soil profile and sampling was based on map overlay between topographical map of 1 : 50.000 scale and geological map of Pangkajene and West Watampone Sheet [4].

The basis for the determination of soil profile observation point for each location is altitude differences of each site, including slope, and geological formation differences in topolithosequence. The map of soil sampling location is presented on a geological map in Fig. 1.

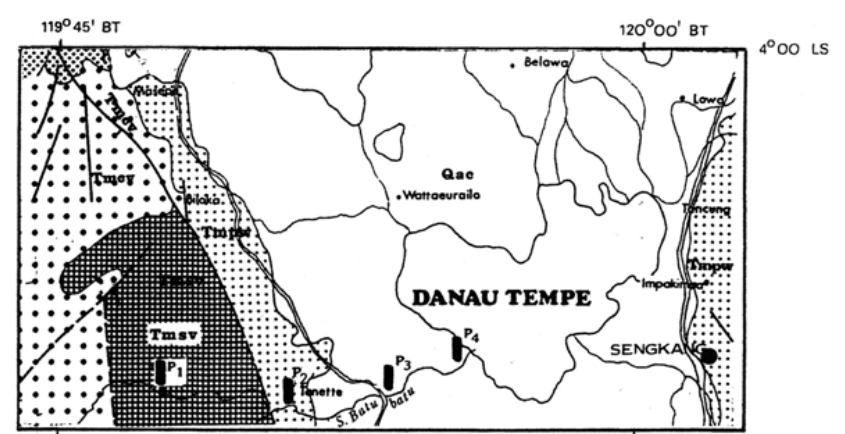

Figure 1. Geological map and soil sampling locations

\subsection{Materials}

The study utilises four soil profiles representing particular zone of topolithosequence. Their distribution begins from the east of Tempe Lake (the depression area) to the west along Batu-Batu river. The soil profile is distributed in the upper, middle, lower slopes, and the depression area of Tempe Lake in the west. The sites are marked respectively from the upper slope to lower slope: P1, P2, P3, and P4. Soil materials (samples) were taken from identified soil horizon in every profile. Morphological characteristics of every area (pedon), was examined using a guidelines for Soil Profile Description [5].

\subsection{Analysis Method}

A mineral can be defined as homogenous natural elements of original inorganic compound, having a fixed chemical compound and a certain geometric shape of molecule arrangement. Minerals have a unique form of crystal that can be used to recognise their types. Other characteristics such as crack section, fragments and glitter together with their shape are important elements in identifying the types of minerals.

The characteristics of the studied minerals consist of sand fraction minerals and clay minerals. The composition of minerals in sand fraction is one of the clues to identify the type of base materials, decomposition rate, and the potentials of soil fertility, while that of clay minerals is closely related to the statuses of physical and chemical of the soil.

Basically, there are two types of mineralogy analysis. First is sand fraction mineral analysis by means of binocular microscope, and second is clay mineral analysis using X-ray Diffraction. Preparation of clay and sand fraction samples was done in the following steps: (a) soil passing through $2 \mathrm{~mm}$ sieve was scaled for 20 gram and put into a $250 \mathrm{ml}$ beaker; (b) ten millilitres of $\mathrm{H}_{2} \mathrm{O}_{2}$ and $100 \mathrm{ml}$ of water were added and boiled in a hot plate. This was done until all organic maters disappear as indicated by bubble disappearance; (c) the soil was then transferred to a porcelain cup and put into oven with a maximum temperature of $50^{\circ} \mathrm{C}$; (d) when the soil sample was getting dried, it was transferred into a $250 \mathrm{ml}$ flask, and $25 \mathrm{ml}$ $\mathrm{Na}$-pyrophosphate; and then $100 \mathrm{ml}$ of water were added to 
it; the sample was then shaken for 4 hours with a shaker machine; (e) the suspension was filtered with a $0.05 \mathrm{~mm}$ sieve to separate sand fraction from dust and clay; (f) suspension which contains dust and clay was filled into a $500 \mathrm{ml}$ precipitating flask added with distilled water to reach $500 \mathrm{ml}$ volume. The flask was then shaken until the suspension and the water were appeared homogenous, and it was allowed by settling it for 6 hours 22 minutes; $(\mathrm{g})$ the suspension was taken out of the flask up to $10 \mathrm{~cm}$ from its upper level and put into an oven on a temperature of $50^{\circ} \mathrm{C}$, until clay fraction was obtained; (h) the clay fraction was then kept in a bottle ready for X-ray diffraction.

Sand fraction samples obtained were first dried to remove water content, and the granular particles were sieved in sieving machine for 15 minutes. The sieving sizes used consecutively are 16 mesh $(0.991 \mathrm{~mm}), 20$ mesh (0.840 mm), 24 mesh $(0.710 \mathrm{~mm}), 32$ mesh $(0.5 \mathrm{~mm}), 116$ mesh $(0.124 \mathrm{~mm})$, plus a container. Every mesh was separated and this study used the grains of 116 mesh or $0.124 \mathrm{~mm}$ because under the microscope the view of these grains looks ideal. Standardization of particle size distribution (PSD) is a prerequisite to achieve compatibility of soil data among various countries with different texture classification systems; great differences in fitting and prediction performance were found between the PSD models. Soil texture as well as the bimodal character of the soil significantly affect their respective performance [6] and [7].

The sand fraction was identified using binocular microscope, following line counting method separating particles based on their colour, shape, crack section, fragment and glitter. The calculation was performed until 100 times with three recurrences. The identification was performed in the laboratory of Sedimentology at Geology Department, Faculty of Engineering, Gadjah Mada University. Meanwhile, the clay fraction obtained was transformed into powder to be used for X-ray diffractogram analysis through the following treatments: oriented, $\mathrm{Mg}^{++}$ Saturation, $\mathrm{Mg}^{++}$with Glycerol, and $\mathrm{K}^{+}$with $550^{\circ} \mathrm{C}$ heating. The treatments were meant to confirm the existence of minerals identified in every profile of each topolithosequence. The analysis was conducted in the laboratory of the Great Hall of Bandung Ceramic Industry. The X-ray Diffractogram identification utilised principles as suggested by [8] and [9].

Sand fraction minerals identified in every profile in this study were: (1) garnet, (2) apatite, (3) olivine, (4) hornblende, (5) biotite, (6) feldspar, (7) muscovite, (8) quartz, (9) hematite, and (10) pyrite.

\section{Results and Discussion}

\subsection{Sand Fraction Minerals}

The distribution of the relative numbers and contents of sand fraction minerals in every soil profile is presented in Table 1.

Table 1. The Distribution of Sand Fraction Minerals of every Soil Profile

\begin{tabular}{crrrrrrrrrr}
\hline \multirow{2}{*}{ Profile Number } & \multicolumn{10}{c}{ Sand Fraction Minerals (\%) } \\
& Garnet & Apatite & Olivine & Hornblende & Biotite & Feldspar & Muscovite & Quarzt & Hematite & Pyrite \\
\hline P.1.1 & 19,33 & 18,67 & 7,67 & 4,00 & - & 20,00 & 3,33 & 13,00 & 6,67 & 7,33 \\
P.2.1 & 14,00 & 21,67 & 9,00 & 8,00 & - & 19,00 & 6,33 & 11,00 & 5,00 & 6,00 \\
P.2.2 & 16,00 & 13,33 & 7,67 & 8,00 & - & 20,33 & 5,67 & 15,00 & 6,00 & 8,00 \\
P.3.1 & 14,33 & 16,67 & 8,33 & 9,00 & - & 19,00 & 7,00 & 13,00 & 8,67 & 4,00 \\
P.3.2 & 14,33 & 20,00 & 7,67 & 7,67 & - & 20,33 & 6,33 & 11,00 & 6,00 & 6,67 \\
P.3.3 & 16,33 & 19,67 & 7,67 & 6,33 & - & 20,33 & 6,67 & 9,67 & 6,00 & 7,33 \\
P.3.4 & 16,00 & 20,00 & 6,67 & 8,33 & - & 21,00 & 3,00 & 11,66 & 6,67 & 6,67 \\
P.4.1 & 17,00 & 15,67 & 6,33 & 8,33 & 1,00 & 19,33 & 5,67 & 14,67 & 6,67 & 5,33 \\
P.4.2 & 17,00 & 15,00 & 6,67 & 7,00 & 0,67 & 19,33 & 5,33 & 17,67 & 6,00 & 5,33 \\
P.4.3 & 6,00 & 21,67 & 8,00 & 6,67 & 0,33 & 20,00 & 5,00 & 18,33 & 7,00 & 7,00 \\
P.4.4 & 7,33 & 20,00 & 5,34 & 10,00 & - & 20,00 & 5,33 & 18,67 & 5,33 & 8,00 \\
P.4.5 & 16,67 & 20,00 & 6,00 & 8,67 & - & 20,00 & 5,33 & 11,33 & 6,00 & 6,00 \\
\hline
\end{tabular}

The identification and observation on every soil profile in general reveals that feldspar, apatite, garnet, and quartz are the dominating ones. Feldspar, garnet, and quartz are silicate group minerals, while apatite is grouped into phosphate minerals.

As stated in the reference [3], mineral stability against decomposition from the one easily decomposable to the one difficultly decomposable, and this can be illustrated in Fig. 2. It is also stated that mineral composition has a specific influence on the development of soil profile. The more the soil contains easily decomposable mineral, the more the clay mineral will be formed.

The ratio between easily decomposable minerals and uneasily decomposable ones can be used to assess the soil development rate. The smaller the ratio, the more developed the soil profile. On the other hand, mineral composition in soil can also be used to determine the origin and the type of the main material. 


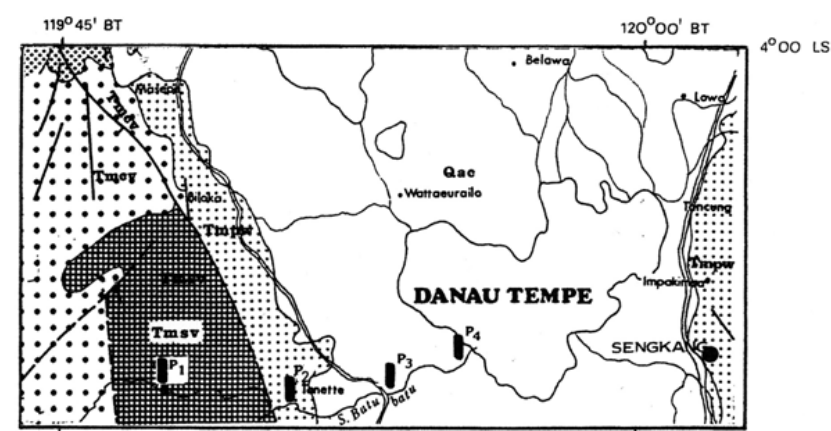

Figure 2. Mineral Stability against Weathering

The result indicates that quartz is fewer than feldspar, apatite, and garnet, but more than olivine, pyrite, hematite, hornblende, biotite, and muscovite. This implies that the soil in general has not yet developed to a more advanced stage.

If the quartz mineral is used as an indication of the soil development rate in its susceptibility nature against weathering, the development stage of the soil among the profiles can be formulated as : P4 $>$ P3 $>$ P2 $>$ P1. The distribution pattern deep down the layer indicates that the soil profile of $\mathrm{P} 1$ has no distribution pattern because it has only one layer (A2 horizon), P2 profile increases, and P3 and $\mathrm{P} 4$ have unfixed distribution pattern. The unfixed distribution pattern of the P3 and P4 are possible due to their respective locations: in the lowest slope and in the depression area of Tempe Lake. It further indicates that heading down toward the slope, following Batu-Batu River, every soil profile has a relationship to each other. That type of relationship is apparent in the $\mathrm{P} 2$ profile (middle slope) towards the depression area of Tempe Lake which makes the P1 profile (upper slope) does not seem to have any relation. This is supported by the distribution pattern of other sand fraction minerals. The pedogenesis is reduced in the lowlands compared with the uplands because the number and volume of the mounds were substantially lower in the bottom and fringe sites compared with the upland site [10] and [11].

\subsection{Clay Minerals}

In this study, X-ray Diffraction is used to determine the clay mineral, while to interpret diffractogram peak, [12] and [13] methods and tables are used. Preliminary treatment of soil sample of every profile is performed as follows:

For P1 and P4 profiles:

a) Oriented sample

b) $\mathrm{Mg}^{++}$saturation

c) $\mathrm{Mg}^{++}$saturation + glycerol

d) $\mathrm{K}^{+}+500^{0}$ heating for 4 hours.

For P2 profile :

a) Oriented sample

b) $\mathrm{Mg}^{++}$saturation c) $\mathrm{Mg}^{++}$saturation + glycerol

While for P3 profile, the treatment only covers:

a) Oriented sample

b) $\mathrm{Mg}^{++}$saturation

The X-ray Diffractogram analysis result of every soil profile presented in Fig. 3. The figure indicates that the diffractogram peaks of $3.2 ; 3.4 ; 3.56 ; 9.9 ; 12.4 ; 14.5 ; 16.8$, and $17.8 \mathrm{~A}^{0}$ are identified as montmorillonite clay mineral, and the diffractogram peaks of 7.2 and $10.1 \mathrm{~A}^{0}$ as halloysite. Meanwhile, the diffractogram peaks of 3.58; 3.59, and 7.15 $\mathrm{A}^{0}$ as kaolinite. With the diffractogram peaks reflected on every soil profile, it could be stated that all soil profiles contain clay minerals montmorillonite, halloysite, and kaolinite, except for profile P1 only contains monmorillonite and halloysite.

Monmorillonite (clay layer 2:1), is commonly called smectite, with chemical formula $\mathrm{Al}_{3} \mathrm{O}_{3} \cdot 4 \mathrm{SiO}_{2} \cdot \mathrm{H}_{2} \mathrm{O}+\mathrm{xH}_{2} \mathrm{O}$. The montmorillonite name is specialised to hydrated aluminium silicate species with a little substitution. The wide range of mineral type is available in the montmorilonite group and in the member of primary end of dioctahedral sub-group i.e., beidelite and nontronite [8]. It is claimed that montmorillonite has $\mathrm{Mg}$ and ferric ions in the ideal position of octahedral and beidelite, having no $\mathrm{Mg}$ and $\mathrm{Fe}$ on the octahedral sheet, while nontronite is similar to beidelite, except that the overall charge of silicate layer of beidelite is the result of the substitution of $\mathrm{Si}^{4+}$ with $\mathrm{Al}^{3+}$. The nontronite substitutes all $\mathrm{Al}^{3+}$ with $\mathrm{Fe}^{3+}$. In the Trioctahedral sub-group, there can be recognised two end members: hectorite and saponite. Table 2 describes the influence of the treatments on Basal Spacing $\mathrm{d}(001)$ (the distance of $d$ ) in $\mathrm{A}^{0}$ of every soil profile and Figure 3 presents the result of X-ray Diffractogram analysis of every soil profile.

Kaolinite (clay layer 1:1) is a hydrated alumina-silicate group with chemical formula of $2 \mathrm{SiO}_{2} . \mathrm{Al}_{2} \mathrm{O}_{3} \cdot 2 \mathrm{H}_{2} \mathrm{O}$ per unit cell. The mineral structure is grouped into phylosilicate type 1:1. In isomorphic substitution of Kaolinite exists only at some degree, and the permanent charge of every unit cell is so small or even nil [13]. The presence of open hydroxyl clusters causes kaolinite to have changing negative charges or a dependency on its $\mathrm{pH}$. The members of kaolinite group are kaolinite, dikite, nakrite, and halloysite. Except for halloysite, other minerals do not expand in water [14].

Colloid migration in subsurface environments has attracted considerable attention in recent years because of its suspected role in facilitating of strongly adsorbed contaminants to groundwater [15]. 

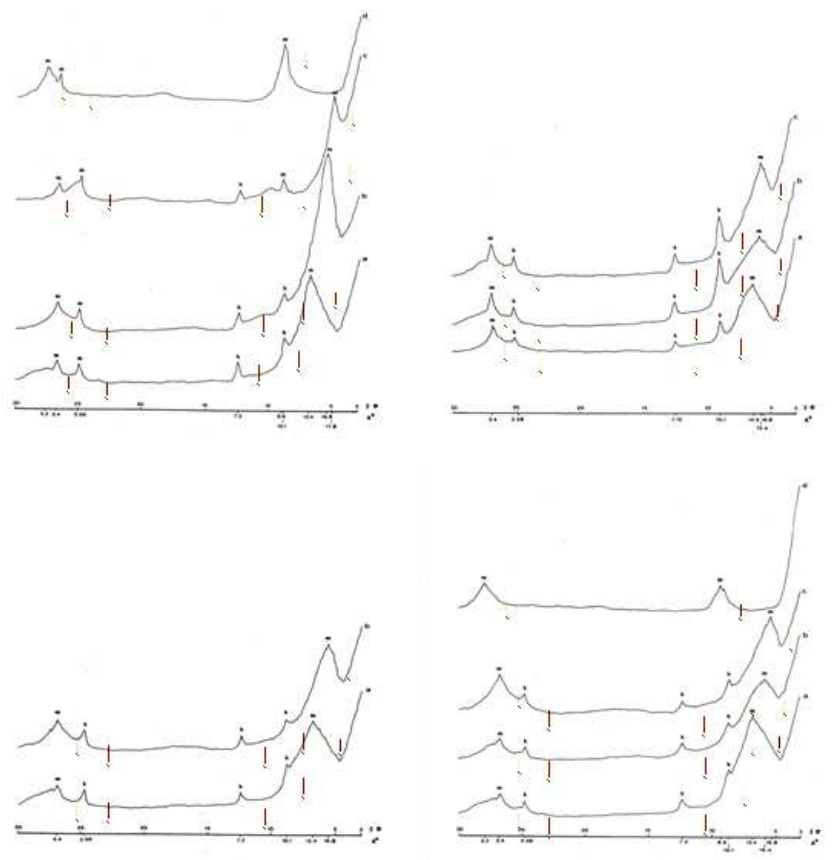

Figure 3. X-ray diffraction of each soil profile

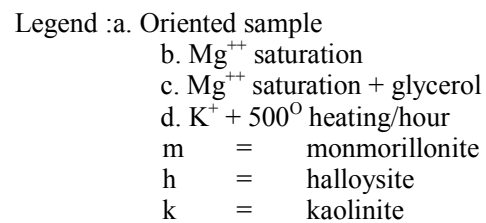

Halloysite (clay layer 1:1) has a chemical formula $\mathrm{Al}_{2} \mathrm{O}_{3} .2 \mathrm{SiO}_{2} .4 \mathrm{H}_{2} \mathrm{O}$. The structure is similar to kaolinite but the difference is in the irregular layer stacking and the presence of two or more layer of water molecules in between layers.

The Result indicate that the smectite component is nearly identical over the soil toposequence; the smectite component is the same with respect to charge magnitude and chemical composition, independent of the proportion of kalinite and smectite component. This suggests the pedogenic formation of K-S by transformation of smectite through dissolution of some smectite layers and subsequent crystallization of kaolinite between the layers of the remaining smectite crystallites [16].

The presence of highly reactive mineral phases, such as low periodic order Mn oxides or allophone-like minerals, with high contents of carbonates is rarely in the natural environment and may suggest an important potential for pedogenic evaluation, which could be directed by the balance between the weathering processes of these phases [17] and [18].

The clay mineralogy reflected the clear weathering trend of the soils along the toposequence; the mineralogical transformations observed along the toposequence indicated that chlorite and serpentine, initially present in the Entisol on the summit, weather into smectite and interstratified chlorite-vermiculite in the intermediate soil on the shoulder under strong leaching and oxidizing conditions [19].

\section{Conclusion}

Sand fraction minerals identified in each profile are Garnet, Apatite, Olivine, Hornblende, Biotite, Feldspar, Muscovite, Quartz, Hematite, and Pyrite. The results of identification, observation, and calculation at every soil profile reveal that the most dominant sand fraction minerals are feldspar, apatite, garnet, and quartz. Feldspar, garnet, and quartz are included in the group of silicate minerals, while apatite is included in Phosphate group. Compared to feldspar, apatite, and garnet, quartz mineral is fewer in number, but compared to olivine, pyrite, hematite, hornblende, biotite, and muscovite, it is more. It could simply be concluded that the soil profile in general has not yet developed. The soil development in the topolithosequence of the studied region when quartz is used as an indication of its development from vulnerability against weathering can be arranged as follows: P4 $>$ P3 $>$ P2 $>$ P 1 .

Furthermore, the X-ray diffractogram analysis of every soil profile indicates that the diffractogram peaks: $3.2 ; 3.4$; $3.56 ; 9.9 ; 12.4 ; 14.5 ; 15.4 ; 16.8$; and $17.8 \mathrm{~A}^{\mathbf{0}}$ are identified as montmorillonite clay mineral, and the diffractogram peaks 7.2 and $10.1 \mathrm{~A}^{\mathbf{0}}$ are halloysite. Meanwhile, the diffrctogram peaks $3.58,3.59$, and $7.15 \mathrm{~A}^{\mathbf{0}}$ are identified as kaolinite. Each soil profile with its diffractogram peak signifies that all profiles have clay mineral montmorillonite, halloysite, and kaolite, except for soil profile P1 only bears montmorillonite, and halloysite. Therefore, it could be concluded that $\mathrm{P} 1$ has experienced longer weathering process than that for P2, P3, and P4, although it never leads to a soil development [20]. A further study on the geological factor needs to be taken to prove whether the catena concept could or could not be used. It is expected that for the sake of soil science and environmental assessment, the variety of geological factors could be minimised. DTA needs to be performed in the analysis of X-ray diffraction in order to be useful in controlling the result of the analysis against the possibility of the existence of amorphous minerals.

\section{Acknowledgements}

The authors would like to thank The Department of Soil Science, Hasanuddin University, and The Department of Geology, Gadjah Mada University for supporting laboratory instruments. We also thank The Center for Regional Development and Spatial Information (WITARIS), Hasanuddin University, for supporting facilities, data, and related information for this study.

\section{References}

[1] Bridges, E. M. and D. A. Davidson, "Principles and applications of soil geography," Longman Inc. New York. 1982.

[2] M. J. Kirkby, Y. Le Bissonais, T.J. Coulthard, J. Daroussin, M.D. McMahon, "The Development of Land Quality Indicators for Soil Degradation by Water Erosion," Journal of 
Agriculture, Ecosystem and Environment. Vol. 81, pp. 125-135. 2000

[3] Buol, S.W., F.D. Hole and R.J. Cracken, "Soil Genesis and Classification," The Iowa State University Press, Ames, Iowa. 1980.

[4] Sukamto, R., "Geological Map", Sheet Pangkajene and West Watampone, Research and Development of Geologi, Bandung, 1982.

[5] Food and Agriculture Organization, "Guidelines for Profile Description”, FAO, Rome, 1977.

[6] Yves-Dady Botula, Wim M. Cornelis, Geert Baert, Paul Mafuka, Eric Van Ranst, "Particle Size Distribution Models for Soil of The Humid Tropics". Journal of Soil and Sediments, Vol. 13, pp. 686-698, April 2013.

[7] Fuyuki Satoh, Toshio Sakuma, and Hideo Okajima. "A Toposequnce of Fine-Textured Soils in the Hilly Area of the Northernmost Part of Hokkaido". Journal Soil Science and Plant Nutrition, Vol. 36, No. 1, pp. 9-11. 1990.

[8] Brindley, G.W. and Brown, G., "Crystal Structures of Clay Minerals and Their X-ray Identification," Mineralogical Society, Monograph No. 5, London, 1980.

[9] De Coninck, F.,'Physico Chemical Aspects of Pedogenesis," ITC-RUG, Belgium, 1978.

[10] Susumu S. Abe, Sadahiro Yamamoto, and Toshiyuki Wakatsuki. "Physicochemical and Morphological Properties of Termite (Macrotermes bellicosus) Mounds and Surrounding Pedons on a Toposequence of an Inland Valley in the Southern Guinea Savanna Zone of Nigeria”. Journal Soil Science and Plant Nutrition, Vol. 55, No. 4, pp. 514-522. 2009.

[11] Fabricio de A.Pedron, Antonio C. de Azevedo, and Ricardo S.D. Dalmolin. "Mineral Weathering in Neossolos in a Climo-Litosequence on the Rio Grande do Sul Plateau, Brazil”. Journal Siencia Rural, Vol. 42, No. 3, March 2012.

[12] Sieffermann, G. and Milliot, G.,"Equatorial and Tropical Weathering of Recent basalt from Cameroun: Allophane, Halloysite, Metahalloysite, Kaolinite, and Gibbsite, Proc. Int.
Clay Conf. Tokyo. 1989.

[13] Moore, D.M. and Reynold, R.C. "X-ray Diffraction and the Identification and Analysis of Clay Minerals", $2^{\text {nd }}$ edition. Oxford University Press, Oxford, 1997.

[14] Wayne P. Robarge. "Mineral: Solubility", Encyclopedia of Soil Science, Second Edition, Published: 12 December 2007.

[15] Dongmei Zhou, Dengjun Wang, Long Cang, Xiuzhen Hao, and Lingyang Chu. "Transport and Re-entrainment of Soil Colloids in Saturated Packed Column: Effects of $\mathrm{pH}$ and Ionic Strength”. Journal of Soils and Sediment, Vol. 11, N0. 3, pp. 491-503. April 2011.

[16] Dominique Righi, Fabio Terribile, and Sabine Petit. "Pedogenic Formation of Kaolinite-Smectite Mixed Layers in a Soil Toposequence Developed From Basaltic Parent Material in Sardinia (Italy)". Journal of Clays and Clay Minerals, Vol. 47, No. 4, pp. 505-514. 1999.

[17] Hermine Hout, M.O. Simonnot, Philippe Marion, Jacques Yvon, Philippe De Donato, J.L. Morel., "Characteristics and Potential Pedogenetic Processes of a Technosol Devoloping on Iron Industry Deposits," Journal of Soil and Sediments, Vol. 13, pp. 555-568, March 2013.

[18] Mostafa Fayek, T. Mark Harrison, Marty Grove, and Christopher D. Coath. "A Rapid In Situ Method for Determining the Ages of Uranium Oxide Minerals: Evaluation of the Cigar Lake Deposit, Athabasca Basin". International Geology Review, Vol. 42, No. 2, July 2010.

[19] Z. Y. Hseu, H. Tsai, H.C. Hsi, and Y.C. Chen. "Weathering Sequences of Clay Minerals in Soils along a Serpentinitic Toposequence". Journal Clays and Clay Minerals. Vol. 55, No. 4, pp. 389-401. August 2007.

[20] Jafari A, Shariatmadari H, Khademi H, Rezainejad Y. "Soil Clay Mineralogy in Four Toposequences from Arid and Semiarid Regions and Its Relationship with Kinetics of Phosphorus Release". JWSS - Isfahan University of Technology. Vol. 12, No.44, pp. 153-168. 2008. 